\title{
Helminthostacys Fern
}

\author{
Teena Agrawal* and Madhu Agrawal* \\ Independent Researcher, Canada
}

Submission: June 21, 2018; Published: July 27, 2018

"Corresponding author: Teena Agrawal, Banasthali University, Rajasthan, India, Tel: +91-9680724243; Email: tagrawal02@gmail.com

Madhu Agrawal, Assistant professor, Banasthali vidhyapeth, Rajasthan, India, Tel: 9694807801; Email: madhugupta9694807801@gmail.com

\section{Abstract}

A pteridophyte are the vascular plant that reproduces by the spores (heterospory) and therefore was a member of the former and now Pteridophyta. The term is now used only informally to denote a fern. Because pteridophytes produce neither flowers nor seeds, they are also referred to as "cryptogams", they are the true lands plants. They are classified by the various way, but overall four of the classes are termed and recognised, these are the Psilopsida, lycopsida, spenopsioda, pteriopsida. Here in this review article we are presenting some of the aspects of the fern Helminthostachys. The genus is related to the family ohiogloaasaceae, the genus consists of the two species, these are termed as the Helminthostays Mexicana, Helminthostacys zeylinica.

Keywords: Ohiogloaasaceae; Pteridophytes; Seeds; Flowers

\section{Introduction}

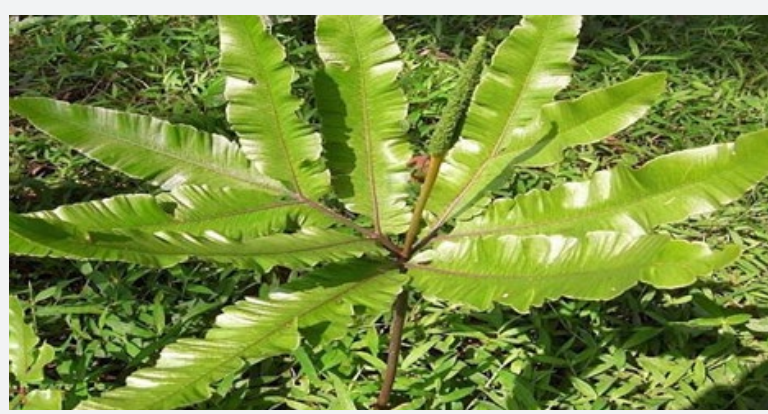

Figure 1: Helminthostacys zeylinica.

The fern is the terrestrial and the herbaceous fern, the fern is endemic of the south eastern Australia and the Asia, the fern is kwon as the tunjuk Lang it, the ferns have the cluster of the storage on the fern like leaves or on the spike like fronds. The rhizome is the short, creeping and the underground, they can bear the solitary fronds or the fronds in the group's leaves are the lanceolate, the margins are of the serrate margin [1-9]. The fern spike arises from the bases of the leaves; the spike is in the form of the stripes. Below the spike there are sterile leave bases. The roots of the $H$. zeylinica are used as the medicines in the china, s "Di wu gong, in Malaysia the leaves are dried, and they are used for stopping the bleeding of the leaves [10]. The plant is eaten as the vegetables, they are also used for the treating the impotence of the peoples the specie is also used as the brain tonic (Figure 1). Several peoples of the world had worked on the phytochemistry of the Helminthostacys zeylinica, they found that the tubers of the ferns are of the good collection of the several metabolites of the pharmacology values, they are found to be the good antioxidants and the good anti-inflammatory effects [1-9]. The leaves also have the very good amount of the phytochemical so if the medicinal values, they are also found very effective in several kinds of the cell lines of the microbial cultures. However human trial is needed for the more and the detailed amount of the work.

\section{Conclusion}

Overall this is the short minireview of the fern Helmintostachys, which shows its distribution and the life pattern.

\section{References}

1) Cantino PD, Doyle James A, Graham Sean W, Judd WS, Olmstead RG, et al. (2007) Towards a Phylogenetic Nomenclature of Tracheophyta. Taxon 56(3): 822-846.

2) Christenhusz MJM, Zhang XC, Schneider H (2011) A linear sequence of extant families and genera of lycophytes and ferns. Phytotaxa 19(1): 7-54.

3) Christenhusz MJ, Chase MW (2014) Trends and concepts in fern classification. Ann Bot 113(4): 571-594.

4) Clark J, Hidalgo O, Pellicer J, Liu H, Marquardt J, et.al (2016) Genome evolution of ferns: evidence for relative stasis of genome size across the fern phylogeny. New Phyto 210(3): 1072-1082.

5) Mark WC, James RL (2009) A phylogenetic classification of the land plants to accompany APG III. Bot J Linn Soc 161 (2): 122-127.

6) Gifford EM, Adriance SF (1996) Morphology and evolution of vascular plants. ( $3^{\text {rd }}$ edn), Freeman WH, New York, Freeman, US.

7) Kenrick Paul, Crane Peter (1996) Embryophytes: Land plants. Tree of Life Web Project. 
8) Paul K, Crane PR (1997) The origin and early evolution of plants on land. Nature 389: 33-39.

his work is licensed under Creative Commons Attribution 4.0 License
9) Ethnobotanical Leaflets at the Wayback Machine, California, USA.

10) Helminthostachys zeylanica.

Your next submission with Juniper Publishers
will reach you the below assets
- Quality Editorial service
- Swift Peer Review
- Reprints availability
- E-prints Service
- Manuscript Podcast for convenient understanding
- Global attainment for your research
- Manuscript accessibility in different formats
( Pdf, E-pub, Full Text, Audio)
- Unceasing customer service
Track the below URL for one-step submission
https://juniperpublishers.com/online-submission.php

